\title{
Dietary-induced increases of disaccharidase activities in rat jejunum
}

\author{
BY BETTY K. SAMULITIS-DOS SANTOS, TOSHINAO GODA* \\ AND OTAKAR KOLDOVSKYे $\dagger$ \\ Department of Pediatrics and Physiology, University of Arizona College of Medicine, Tucson, \\ Arizona 85724, USA and The Committee on Nutritional Sciences, University of Arizona, Tucson, \\ Arizona 85721, USA
}

(Received 17 December 1990 - Accepted 22 May 1991)

\begin{abstract}
A study was carried out to examine whether the responsiveness of small intestinal epithelial cells to dietary carbohydrate varied during the daily $24 \mathrm{~h}$ cycle. The effect of sucrose on disaccharidase activities was compared during a period of decreasing disaccharidase activities, i.e. between 22.00 and 10.00 hours, and increasing disaccharidase activities, i.e. between 10.00 and 22.00 hours, in the jejunum of 7-weekold-rats. Rats were fed on a low-starch, high-fat diet (Lst; starch 5 and fat $73 \%$ of gross energy), or a high-starch, low-fat diet (Hst; starch 70 and fat $7 \%$ of gross energy). Both dietary groups exhibited typical diurnal variations in jejunal sucrase $(E C$ 3.2.1.48), maltase $(E C$ 3.2.1.20) and lactase $(E C 3.2 .1 .23)$ activities, exhibiting a peak around 22.00 hours and a trough at approximately 10.00 hours. When rats were fed on diet Lst for $7 \mathrm{~d}$ and then force-fed on an isoenergetic sucrose diet (S; sucrose 40 and fat $37 \%$ of gross energy) for 6 or $12 \mathrm{~h}$ they exhibited increased sucrase, maltase and lactase activities compared with rats fed on diet Lst. The absolute increase in disaccharidase activities was similar regardless of the time diet $S$ was given or whether rats were killed at 10.00 hours or at 22.00 hours. Analyses of sucrase and lactase activities along the villus-crypt columns showed that the distribution of cell cohorts that responded to diet $S$ was not influenced by the time of introduction of diet $S$. These findings suggest that small intestinal epithelial cells possess the ability to respond to dietary carbohydrate throughout the daily $24 \mathrm{~h}$ cycle.
\end{abstract}

Dietary carbohydrate: Diurnal rhythm: Disaccharidase activity

Four distinct disaccharidase complexes, sucrase-isomaltase (EC 3.2.1.48, EC 3.2.1 10), glucoamylase-maltase ( $E C$ 3.2.1.3, EC 3.2.1.20), lactase (EC 3.2.1.23, EC 3.2.1.62), and trehalase (EC 3.2.1.28) exist in the small intestinal epithelial cells of nearly all mammals (Semenza, 1986). In the rat small intestine, a rapid alteration of disaccharidase activity can be induced by dietary manipulation. Within $3 \mathrm{~h}$ of feeding a sucrose-containing diet (for review, see Goda \& Koldovsky, 1988) the activity and immunological amount of sucrase-isomaltase (Cézard et al. 1983; Goda et al. 1985) and lactase (Goda et al. 1985) increase in the rat small intestine. This dietary-induced increase of sucrase and lactase activities is observed along the entire height of the villus, suggesting that not only immature crypt cells but also differentiated villus cells possess the capability of responding to a change in dietary carbohydrate (Yamada et al. 1981 a; Cézard et al. 1983; Goda et al. 1985).

In addition to the dietary-induced fluctuation in disaccharidase activities, disaccharidase activities show a typical diurnal pattern. In the rat small intestine, disaccharidase activities

\footnotetext{
* Present address: School of Food and Nutritional Sciences, Laboratory of Nutritional Physiology, The University of Shizuoka, 395 Yada, Shizuoka City, Shizuoka 422, Japan.

$\uparrow$ Address for reprints: Department of Pediatrics, University of Arizona College of Medicine, Tucson, Arizona 85724 , USA
} 
Table 1. Composition of diets*

\begin{tabular}{|c|c|c|c|c|c|c|}
\hline \multirow[b]{2}{*}{ Ingredient } & \multicolumn{2}{|c|}{ Low-starch } & \multicolumn{2}{|c|}{ High-starch } & \multicolumn{2}{|c|}{ Sucrose } \\
\hline & $\mathrm{MJ} / \mathrm{kg}$ & $\mathrm{g} / \mathrm{kg}$ & $\mathrm{MJ} / \mathrm{kg}$ & $\mathrm{g} / \mathrm{kg}$ & $\mathrm{MJ} / \mathrm{kg}$ & $\mathrm{g} / \mathrm{kg}$ \\
\hline Casein & 2.66 & $159 \cdot 0$ & $2 \cdot 63$ & $157 \cdot 0$ & $2 \cdot 78$ & $166 \cdot 0$ \\
\hline Maize starch & 0.60 & $36 \cdot 0$ & $8 \cdot 80$ & $526 \cdot 0$ & $\ldots$ & - \\
\hline Sucrose & - & - & - & - & $5 \cdot 15$ & $308 \cdot 0$ \\
\hline Maize oil & $9 \cdot 30$ & 247.0 & 0.90 & $24 \cdot 0$ & $4 \cdot 71$ & $125 \cdot 0$ \\
\hline AIN $^{76}$ Mineral mix $\dagger$ & 0.06 & $28 \cdot 0$ & 0.06 & 28.0 & 0.06 & $28 \cdot 0$ \\
\hline AIN $^{76}$ Vitamin mix $\dagger$ & $0 \cdot 13$ & 8.0 & 0.13 & $8 \cdot 0$ & $0 \cdot 13$ & 8.0 \\
\hline DL-methionine & 0.04 & $2 \cdot 4$ & 0.04 & $2 \cdot 4$ & 0.04 & $2 \cdot 4$ \\
\hline Choline bitartrate & $0 \cdot 00$ & 1.6 & 0.00 & 1.6 & $0 \cdot 00$ & 1.6 \\
\hline Agar $(20 \mathrm{~g} / \mathrm{kg})$ & 0.00 & $518 \cdot 0$ & 0.00 & $253 \cdot 0$ & $0 \cdot 00$ & $361 \cdot 0$ \\
\hline Total & 12.79 & 1000 & $12 \cdot 56$ & 1000 & $12 \cdot 87$ & 1000 \\
\hline
\end{tabular}

* For force-fed diets, agar was omitted and diets were diluted with water $(300 \mathrm{ml} / \mathrm{kg}$ diet). Gross energy contents of diets were estimated with an assumption that carbohydrate and protein provide $16.7 \mathrm{~kJ} / \mathrm{g}$ and fat provides $37.7 \mathrm{~kJ} / \mathrm{g}$. These were expressed on a dry weight basis.

$+\mathrm{AIN}^{76}$ Mineral mix contains $118 \mathrm{~g}$ sucrose $/ \mathrm{kg}$ and $\mathrm{AIN}^{76}$ Vitamin mix contains $993 \mathrm{~g}$ sucrose/ $\mathrm{kg}$ (American Institute of Nutrition, 1977).

exhibit a diurnal variation with a peak during the dark hours and a trough during the light hours (Saito, 1972; Saito et al. 1975; Stevenson et al. 1975). Food consumption appears to be an important factor affecting the diurnal variation of disaccharidase activities, since a shift in meal-time during the light hours leads to a corresponding shift in the time of peak disaccharidase activity (Saito, 1972; Saito et al. 1975, 1976; Stevenson et al. 1975). These earlier studies led us to question whether the ability of small intestinal epithelial cells to respond to dietary carbohydrate is influenced by the diurnal variation of disaccharidase activities.

\section{MATERIALS AND METHODS}

\section{Animals}

Female Sprague-Dawley rats born in the Department's animal colony were weaned at $30 \mathrm{~d}$ of age and fed on a standard laboratory diet (Lab Blox; Allied Mills, Chicago, IL) until $50 \mathrm{~d}$ of age. The rats were housed under a light cycle with $12 \mathrm{~h}$ darkness from 18.00 to 06.00 hours. Each treatment group consisted of four rats unless otherwise stated.

\section{Experimental methods}

Expts 1 and 2. To determine the normal diurnal variation of disaccharidase activities under different dietary carbohydrate intakes, 50-d-old rats (fourteen rats per group) were fed on either a synthetic low-starch, high-fat diet (Lst; starch 5 and fat $73 \%$ of gross energy) or a synthetic high-starch, low-fat diet (Hst; starch 70 and fat $7 \%$ of gross energy) for $14 \mathrm{~d}$ (Yamada et al. 1981 b; see Table 1). On days 7 and 11, the rats were housed in individual cages and the food intakes measured individually every $3 \mathrm{~h}$ for $24 \mathrm{~h}$. On day 14 , the rats were killed by decapitation at $09.00,12.00,15.00,21.00,24.00$ or 03.00 hours. In the second experiment, the rats were killed by decapitation at 10.00 or 22.00 hours on day 7 of the study.

Expts 3 and 4. The third and fourth studies were designed to study the short-term effects of increasing the quantity of dietary carbohydrate at different times of the day. At $50 \mathrm{~d}$ of 
age, rats were fed on either diet Lst or sucrose diet (S; sucrose 40 and fat $37 \%$ of gross energy) for $7 \mathrm{~d}$ (see Table 1). On day 7, rats that were on diet Lst were switched to liquefied diets equivalent to either diet Lst or diet S. These diets were given orogastrically for $6 \mathrm{~h}$ (Expt 3) or $12 \mathrm{~h}$ (Expt 4) before the rats were killed to control precisely the dietary intakes of the two groups (Goda et al. 1984, 1985). Rats fed on diet S for $7 \mathrm{~d}$ were continued on the same diet ad lib. until they were killed.

The gross energy content of the liquefied diets was $9.9 \mathrm{~kJ} / \mathrm{ml}$. Force-feeding was performed three times in $12 \mathrm{~h}$ (Expt 3), i.e. at 22.00, 02.00 and 06.00 hours, or at 10.00 , 14.00 and 18.00 hours, or twice in $6 \mathrm{~h}$ (Expt 4), i.e. at 04.00 and 07.00 hours, or at 16.00 and 19.00 hours. The amount of diet given was $314 \mathrm{~kJ} / \mathrm{kg}$ body-weight (BW) per $6 \mathrm{~h}$ and $837 \mathrm{~kJ} / \mathrm{kg} \mathrm{BW}$ per $12 \mathrm{~h}$. These amounts corresponded to the ad lib. intake of diet Lst recorded between 03.00 and 09.00 hours (for Expt 3) and between 21.00 and 09.00 hours (for Expt 4) respectively (see Fig. 1). In both experiments, the animals were killed by decapitation at 10.00 or 22.00 hours.

All synthetic diets described previously, including liquefied formulas, were prepared in this laboratory (Goda et al. 1984, 1985). Rats had free access to water throughout the entire experiment.

\section{Preparation of intestinal samples}

The entire small intestine was removed and the duodenum discarded, and the jejuno-ileum was divided into three segments of equal length. The proximal (upper jejunum), middle (lower jejunum) and distal (ileum) portions were separately flushed with $10 \mathrm{ml}$ ice-cold saline ( $9 \mathrm{~g}$ sodium chloride/l) solution. The intestinal flushings were collected to assay for trypsin activity. The mucosa of the proximal jejunum was scraped with a glass slide on ice and homogenized with $10 \mathrm{~mm}$-potassium phosphate buffer $(\mathrm{pH} \mathrm{7.0)}$ ). Tissue preparations and intestinal flushings were stored at $-20^{\circ}$ before assaying.

\section{Determination of disaccharidase activity gradient along the villus-crypt axis}

To assay the activities of sucrase and lactase at different heights along the villus-crypt columns, a $5 \times 5 \mathrm{~mm}$ segment of the middle portion of the upper jejunum was sectioned with a cryostat at $-18^{\circ}$, and the gradient of these enzyme activities along the villus-crypt axis was determined as described previously (Goda et al. 1983).

\section{Enzyme assays}

Sucrase, lactase, maltase and trehalase activities were assayed according to the method of Dahlqvist (1964). The lactase assay mixture contained $p$-hydroxymercuribenzoate (Aldrich, Milwaukee, WI) to inhibit any residual lysosomal acid $\beta$-galactosidase $(E C$ 3 2.1 .23 ) activity (Koldovskỳ et al. 1969). Trypsin activity was determined according to the method of Erlanger et al. (1961) without preincubation with enterokinase (EC 3.4.21.9). All enzyme determinations were made under conditions of linear activity with time and concentration of the enzyme. Protein was determined according to the method of Lowry et al. (1951) using bovine serum albumin as standard.

\section{Statistical analysis}

Results were expressed as means with their standard errors. Means of the different groups were compared by one-way analysis of variance, followed by Student's $t$ test. When the effects of dietary manipulations and the effects of time were analysed simultaneously, a two-way analysis of variance was performed. For statistical analysis on the repeated 
measurements over time and over the length of the villus-crypt columns, a separate analysis of variance was carried out for each height of the villus-crypt columns.

\section{RESULTS}

Expts 1 and 2. Diurnal variation of disaccharidase activities in rats fed on the low-and high-starch diets

To examine whether the level of dietary carbohydrate affects the diurnal variation of small intestinal disaccharidase activities, rats were fed on either diet Lst or diet Hst ad lib. for $14 \mathrm{~d}$. Food intake for a $24 \mathrm{~h}$ period on day 7 was recorded at $3 \mathrm{~h}$ intervals to compare the pattern of ad lib. intake between the two dietary groups. Except for a $3 \mathrm{~h}$ period between 21.00 and 24.00 hours, rats of both dietary groups consumed comparable amounts throughout the $24 \mathrm{~h}$ period (Fig. 1). Between 21.00 and 24.00 hours, the rats fed on diet Lst consumed $28 \%$ less than the rats fed on diet Hst $(P<0.05)$. However, there was no significant difference in total energy intake per $\mathrm{kg} \mathrm{BW}$ over the $24 \mathrm{~h}$ period. Mean daily energy intake on diet Lst was $1460($ SEM 75) kJ/kg BW (n 14) and on diet Hst 1670 (SEM 92), $\mathrm{kJ} / \mathrm{kg} \mathrm{BW}$ ( $n$ 14). Being nocturnal, rats in both dietary groups consumed more energy $(P<0.001)$ during the dark hours of $18.00-06.00$ hours when mean energy intake on diet Lst was 970 (SEM 59), $\mathrm{kJ} / \mathrm{kg} \mathrm{BW}(n$ 14) and on diet Hst was 1140 (SEM $38) \mathrm{kJ} / \mathrm{kg} \mathrm{BW}(n 14)$, than during the light hours of $06.00-18.00$ hours when mean energy intake on diet Lst was 490 (SEM 50 ) kJ/kg BW ( $n$ 14) and on diet Hst 540 (SEM 80) $\mathrm{kJ} / \mathrm{kg} \mathrm{BW}$ ( $n$ 14; see Fig. 1). The diurnal pattern and the absolute amount of ad lib. intake of the two dietary groups on day 11 was similar to that observed on day 7 (values not shown).

After giving diets Lst or Hst for $7 \mathrm{~d}$, no significant difference in BW, jejunal mucosal weight or total jejunal mucosal protein was observed between the two dietary groups (values not shown). Furthermore, the jejunal mucosal weight and the jejunal total protein in rats killed at 10.00 hours was similar to that of rats killed at 22.00 hours regardless of diet consumed (values not shown).

In Expt. 1 we saw a cyclic diurnal pattern of increasing and decreasing sucrase, maltase and lactase activities in the jejunum of rats fed on diets Lst and Hst ad lib. for $14 \mathrm{~d}$ (Fig. $2 a-c)$. The peak occurred at night $(21.00-24.00$ hours) and a minimum occurred approximately $12 \mathrm{~h}$ later (09.00-12.00 hours). A similar cyclic pattern of trehalase activity was seen in rats fed on diet Hst, but not in rats fed on diet Lst (Fig. $2 d$ ). Accordingly, two times, 10.00 and 22.00 hours, were selected to represent the trough and peak of disaccharidase activities in subsequent studies.

The result of the second experiment is shown in Table 2. Sucrase, maltase, and lactase activities were significantly elevated $(P<0.001)$ at 22.00 hours when compared with the corresponding activities at 10.00 hours in rats fed on diets Lst or Hst. Trehalase activity was elevated at 22.00 hours, compared with 10.00 hours, but only in rats fed on diet Hst. Sucrase, maltase and lactase activities in rats fed on diet Hst were always higher than those of rats fed on diet Lst, whether they were killed at 10.00 or 22.00 hours. In contrast, trehalase activity of rats fed on diet Hst was higher than that of rats fed on diet Lst only at night; no dietary effect was observed in rats killed at 10.00 hours (Table 2).

Thus, a diurnal variation of sucrase, maltase, and lactase activities was maintained regardless of dietary regimen, whereas a diurnal variation of trehalase activity was maintained only in rats fed on diet Hst.

Since proteases present in the lumen of the small intestine can influence disaccharidase activities (Alpers \& Tedesco, 1975; Goda \& Koldovskỳ, 1985; Riby \& Kretchmer, 1985; Goda et al. 1988), lumen trypsin activity of the proximal, middle and distal segments of the 


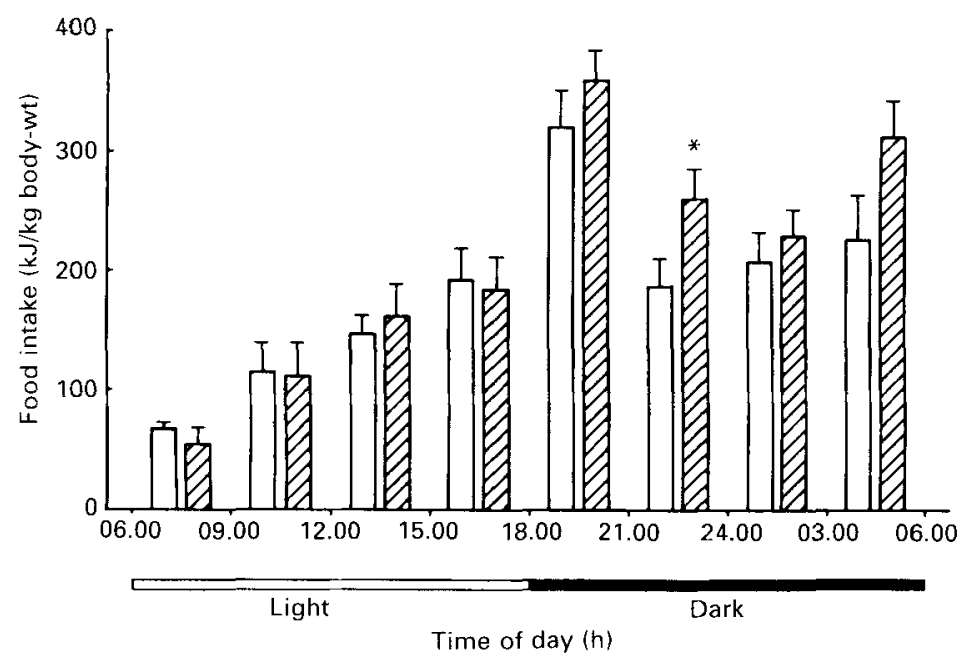

Fig. 1. Expt. 1. Energy intake (kJ/kg body-weight) during one $24 \mathrm{~h}$ time-period ( 7 th day) in rats on ad lib. low starch (Lst; $\square$ ) or high-starch ( $\square$ ) diets (for details of compositions, see Table 1). Energy intakes during the $3 \mathrm{~h}$ time-periods were measured at $09.00,12.00,15.00,18.00,21.00,24.00,03.00$ and 06.00 hours. Values are means of fourteen rats. Mean value was significantly different from that of rats fed on diet Lst: ${ }^{*} P<0.05$.

jejuno-ileum was compared between the two dietary groups as well as between the two times. There was no diurnal variation of lumen trypsin activity in rats fed on diets Lst or Hst, nor was any difference seen in rats killed at either 10.00 or 22.00 hours (values not shown).

\section{Expts 3 and 4. Diurnal variation of dietary-induced increase of disaccharidase activities}

Based on information obtained in the first two experiments, experiments were conducted to determine if the dietary-induced modification of disaccharidase activities (i.e. response of disaccharidase activities to changes in amount of carbohydrate intake) was affected by the time of day when the diet was introduced. The aim was to establish if the response of disaccharidase activities to a change in carbohydrate intake differs if the change in carbohydrate intake occurs between 22.00 and 10.00 hours (a period of decreasing disaccharidase activities) or between 10.00 and 22.00 hours (a period of increasing disaccharidase activity).

Rats were fed on diet Lst for $7 \mathrm{~d}$, then given diet S or diet Lst for 6 or $12 \mathrm{~h}$. The total jejunal protein content was not significantly different between the rats fed on diet $\mathrm{S}$ or diet Lst for 6 or $12 \mathrm{~h}$ regardless of time of killing (values not shown). Force-feeding of diet $S$ to rats initially fed on diet Lst led to a significant increase in sucrase, maltase, and lactase activities within $6 \mathrm{~h}$ compared with those levels in rats force-fed with diet Lst for the same time-period (Table 3). The absolute difference between the two groups in sucrase, maltase, and lactase activities at 10.00 hours was similar to that observed at 22.00 hours. However, when the difference was expressed as a percentage of the values measured in the Lst-fed group, a greater increase in sucrase, maltase, and lactase activities occurred at 10.00 hours than at 22.00 hours, i.e. sucrase activity increased by $70 \%$ at 10.00 hours but only $28 \%$ at 22.00 hours, maltase activity increased by $41 \%$ at 10.00 hours but only $22 \%$ at 22.00 hours, and lactase activity increased by $43 \%$ at 10.00 hours but only $28 \%$ at 22.00 hours. The elevated levels of sucrase, maltase, and lactase activities caused by force-feeding with diet $\mathrm{S}$ did not approach the levels of disaccharidase activities seen in rats that were fed on diet $\mathrm{S}$ ad lib. throughout the entire experimental period (results not shown). Force-feeding with 

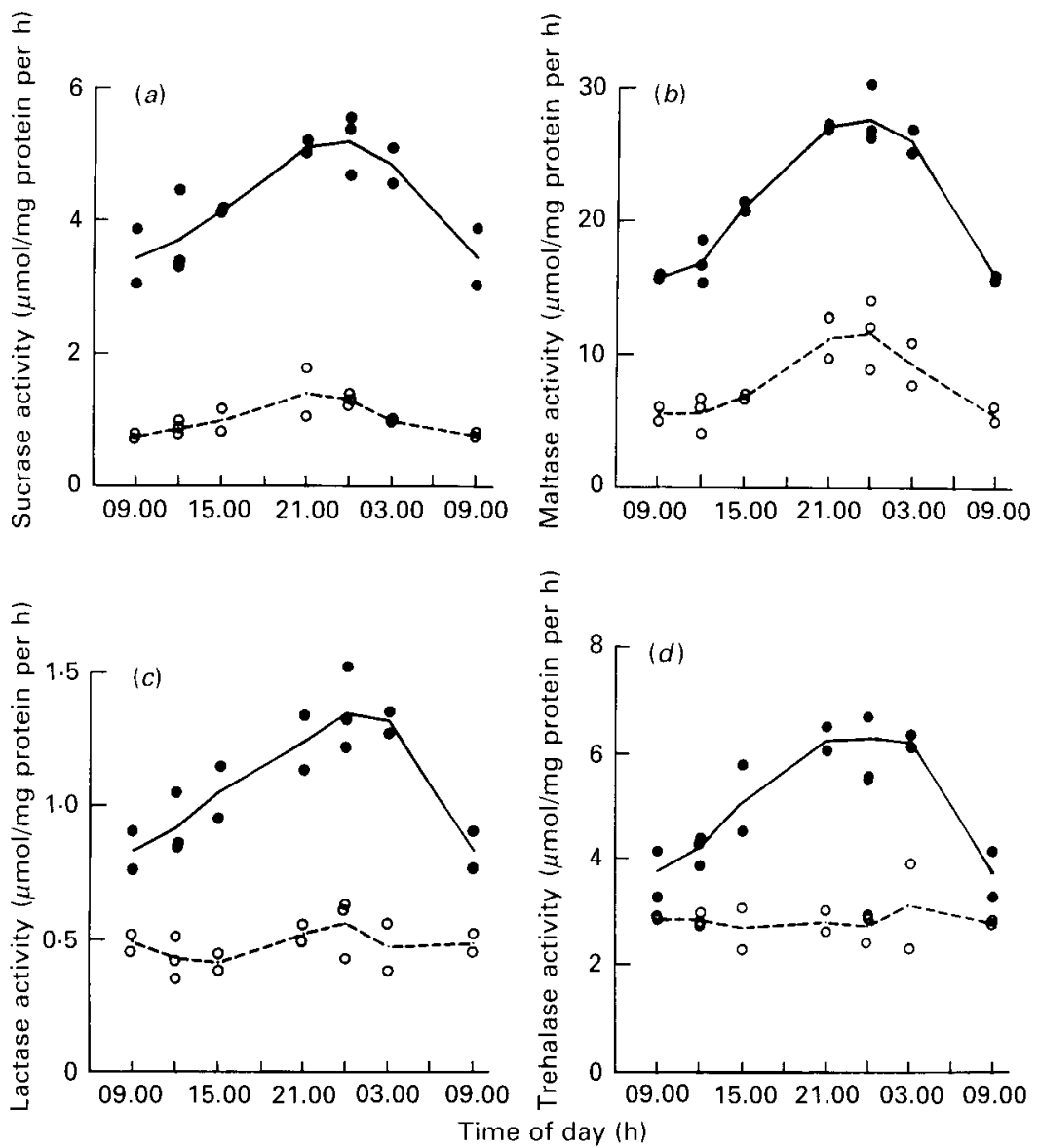

Fig, 2. Expt. 1. Diurnal variation of $(a)$ sucrase $(E C 3.2 .1 .48)$, (b) maltase $(E C 3.2 .1 .20)$, (c) lactase $(E C$ 3.2.1.23), and $(d)$ trehalase $(E C$ 3.2.1.28) activities in the proximal jejunum of rats on $a d$ lib. low-starch (O) or high-starch (O) diets for $14 \mathrm{~d}$. For details of diets, see Table 1. For details of procedures, see pp. 268-269.

diet $\mathrm{S}$ for $6 \mathrm{~h}$ led to a slight increase in trehalase activity in the morning and afternoon (Table 3). However, there was no significant interaction between diet effect and time effect.

Giving diet $\mathrm{S}$ for $12 \mathrm{~h}$ to rats initially fed on diet Lst resulted in a significant increase in sucrase, maltase and lactase activities (Table 4) at 10.00 hours and 22.00 hours; trehalase activity was not measured. As observed in the $6 \mathrm{~h}$ feeding experiment, the absolute difference in sucrase, maltase, and lactase activities between the two dietary groups as a result of giving diet $\mathrm{S}$ for $12 \mathrm{~h}$ was identical for each disaccharidase regardless of the time of day when diet $\mathrm{S}$ was given (Table 4). Again there was no significant interaction between diet effect and time effect.

\section{Response of sucrase and lactase activities along the villus-crypt columns to dietary carbohydrate}

In the subsequent studies, we explored whether the distribution along the villus-crypt columns of enterocytes that responded to diet $\mathrm{S}$ was influenced by a diurnal rhythm (Figs 3 and 4 ). When the rats were force-fed for $6 \mathrm{~h}$ and killed at 10.00 hours, sucrase activity in rats fed on diet $\mathrm{S}$ was significantly higher in the lower part of the villus (e.g. $P<0.05$ at 55 
Table 2. Expt. 2*. Sucrase (EC 3.2.1.48), maltase (EC 3.2.1.20), lactase (EC 3.2.1.23) and trehalase (EC 3.2.1.28) activities $\dagger$ in the jejunal mucosa of rats fed on a low-starch or high-starch diet ad lib. for $7 d$

(Mean values for four rats per group)

\begin{tabular}{|c|c|c|c|c|}
\hline & Sucrase & Maltase & Lactase & Trehalase \\
\hline $\begin{array}{l}\text { Low-starch diet } \$ \\
10.00 \text { hours } \$ \\
22.00 \text { hours }\end{array}$ & $\begin{array}{l}0.87 \\
1.63\end{array}$ & $\begin{array}{r}6.97 \\
12.24\end{array}$ & $\begin{array}{l}0.259 \\
0.415\end{array}$ & $\begin{array}{l}3.86 \\
3.85\end{array}$ \\
\hline $\begin{array}{l}\text { High-starch diet }+ \\
10.00 \text { hours } \\
22.00 \text { hours }\end{array}$ & $\begin{array}{l}3 \cdot 51 \\
5 \cdot 46\end{array}$ & $\begin{array}{l}14 \cdot 48 \\
29 \cdot 16\end{array}$ & $\begin{array}{l}0.619 \\
1.105\end{array}$ & $\begin{array}{l}3.42 \\
6.03\end{array}$ \\
\hline $\operatorname{SED}(12 \mathrm{df})$ & $0 \cdot 24$ & 0.98 & 0.055 & $0 \cdot 29$ \\
\hline $\begin{array}{l}\text { Statistical significance of com } \\
\text { Low-starch } v \text {. high-starch } \\
10.00 \text { hours } v .22 .00 \text { hours } \\
\text { Interaction }\end{array}$ & $\begin{array}{l}\text { ons: } P \\
<0.001 \\
<0.001 \\
<0.05\end{array}$ & $\begin{array}{l}<0.001 \\
<0.001 \\
<0.001\end{array}$ & $\begin{array}{l}<0.001 \\
<0.001 \\
<0.025\end{array}$ & $\begin{array}{l}<0.025 \\
<0.001 \\
<0.001\end{array}$ \\
\hline
\end{tabular}

SED, standard error of difference.

* For details of procedures, see pp. 268-269.

$\dagger$ Disaccharidase activities are expressed as $\mu \mathrm{mol} / \mathrm{mg}$ protein per $\mathrm{h}$.

\$For details of diets, see Table 1 .

$\S$ Time of killing.

Table 3. Expt. 3*. Sucrase (EC 3.2.1.48), maltase (EC 3.2.1.20), lactase (EC 3.2.1.23) and trehalase (EC 3.2.1.28) activities in the jejunal mucosa of rats fed on a low-starch diet for $7 d$ and then force-fed a low-starch diet or a sucrose diet during the last $6 \mathrm{~h}$

(Mean values for four rats per group)

\begin{tabular}{|c|c|c|c|c|}
\hline & Sucrase & Maltase & Lactase & Trehalase \\
\hline \multicolumn{5}{|l|}{ Low-starch diet $\$$} \\
\hline 10.00 hours $\S$ & $0 \cdot 59$ & $4 \cdot 60$ & $0 \cdot 344$ & $2 \cdot 00$ \\
\hline 22.00 hours & $1 \cdot 60$ & $10 \cdot 10$ & $0 \cdot 487$ & $2 \cdot 43$ \\
\hline \multicolumn{5}{|l|}{ Sucrose diet $\ddagger$} \\
\hline 10.00 hours & $1 \cdot 01$ & 6.49 & 0.491 & $2 \cdot 52$ \\
\hline 22.00 hours & $2 \cdot 05$ & $12 \cdot 36$ & 0.625 & 3.00 \\
\hline SED $(12 \mathrm{df})$ & $0 \cdot 12$ & $0 \cdot 61$ & 0.059 & $0 \cdot 22$ \\
\hline \multicolumn{5}{|c|}{ Statistical significance of comparisons: $P$} \\
\hline Low-starch $v$. sucrose & $<0.05$ & $<0.01$ & $<0.05$ & $<0.05$ \\
\hline 10.00 hours $v .22 .00$ hours & $<0.001$ & $<0.001$ & $<0.05$ & $<0.05$ \\
\hline Interaction & NS & NS & NS & NS \\
\hline
\end{tabular}

SED, standard error of difference.

* For details of procedures, see pp. 268-269.

$\dagger$ Disaccharidase activities are expressed as $\mu \mathrm{mol} / \mathrm{mg}$ protein per $\mathrm{h}$.

\$ For details of diets, see Table 1 .

$\S$ Time of killing.

and $45 \%$ of villus-crypt columns) as compared with that of rats on diet Lst (Fig. $3(a)$ ). However, lactase activity was elevated following diet $S$ at the upper part of the villus, e.g. $P<0.01$ at 85,75 and $65 \%$ of villus-crypt columns (Fig. $4(a)$ ). In the rats killed at 22.00 hours, the locus of the enterocytes along the villus-crypt columns that responded with an 


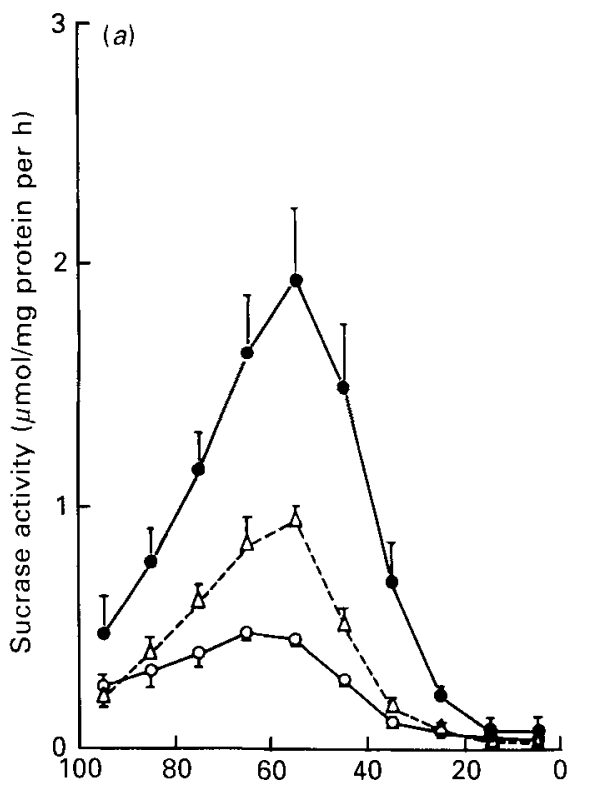

Total height of intestinal wall $(\%$ of height)

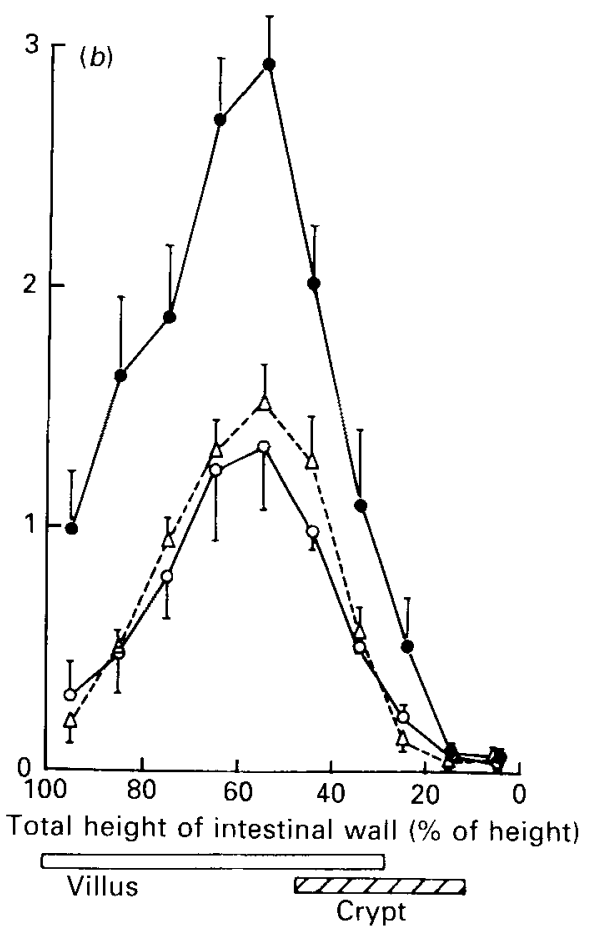

Fig. 3. Expt. 3. Sucrase (EC 3.2.1.48) activity along the villus crypt columns $6 \mathrm{~h}$ after the initiation of forcefeeding of the sucrose diet. The rats were killed at $(a) 10.00$ hours or $(b) 22.00$ hours. The abscissa shows the total height of the intestinal wall, with $100 \%$ representing the apical part of the villus and $0 \%$ representing the bottom of the serosal side. ( $\square$ ), Villus region; $(\square)$, crypt region; the overlapping area is the crypt-villus transition (mix) zone. Points are means with their standard errors represented by vertical bars for four rats. (O), Low-starch diet (control); $(\triangle)$, sucrose diet for $6 \mathrm{~h} ;(\bigcirc)$, sucrose diet for the entire experimental period.

Table 4. Expt. 4*. Sucrase (EC 3.2.1.48), maltase (EC 3.2.1.20) lactase (EC 3.2.1.23) activities $\dagger$ in the jejunal mucosa of rats fed on a low-starch diet for $7 d$ and then force-fed a low-starch diet or a sucrose diet during the last $12 \mathrm{~h}$

(Mean values for four rats per group)

\begin{tabular}{|c|c|c|c|}
\hline & Sucrase & Maltase & Lactase \\
\hline \multicolumn{4}{|l|}{ Low-starch diet } \\
\hline 10.00 hours $\$$ & 0.92 & $8 \cdot 10$ & $0 \cdot 573$ \\
\hline 22.00 hours & $1 \cdot 24$ & $12 \cdot 71$ & 0.556 \\
\hline \multicolumn{4}{|l|}{ Sucrose diet +} \\
\hline 10.00 hours & $2 \cdot 02$ & $16 \cdot 01$ & 1.007 \\
\hline 20.00 hours & $2 \cdot 31$ & $19 \cdot 45$ & 0.972 \\
\hline $\operatorname{SED}(12 \mathrm{df})$ & 0.09 & 0.84 & 0.057 \\
\hline \multicolumn{4}{|c|}{ Statistical significance of comparisons: $P$} \\
\hline Low-starch $v$. sucrose & $<0.001$ & $<0.001$ & $<0.001$ \\
\hline 10.00 hours $* 22.00$ hours & NS & $<0.005$ & NS \\
\hline Interaction & NS & NS & NS \\
\hline
\end{tabular}

SED, standard error of difference.

* For details of procedures, see pp. 268-269.

$\dagger$ Disaccharidase activities are expressed as $\mu \mathrm{mol} / \mathrm{mg}$ protein per $\mathrm{h}$.

$\ddagger$ For details of diets, see Table 1 .

$\S$ Time of killing. 

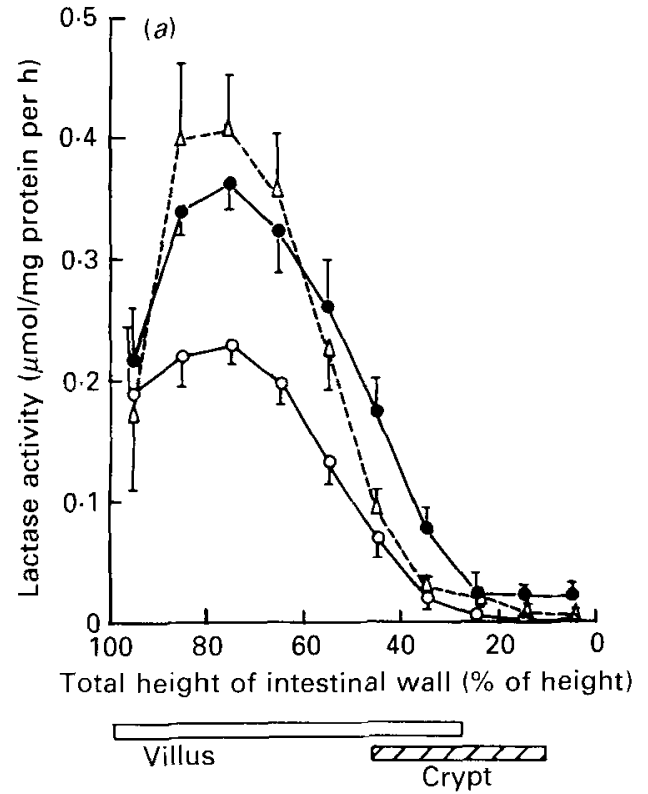

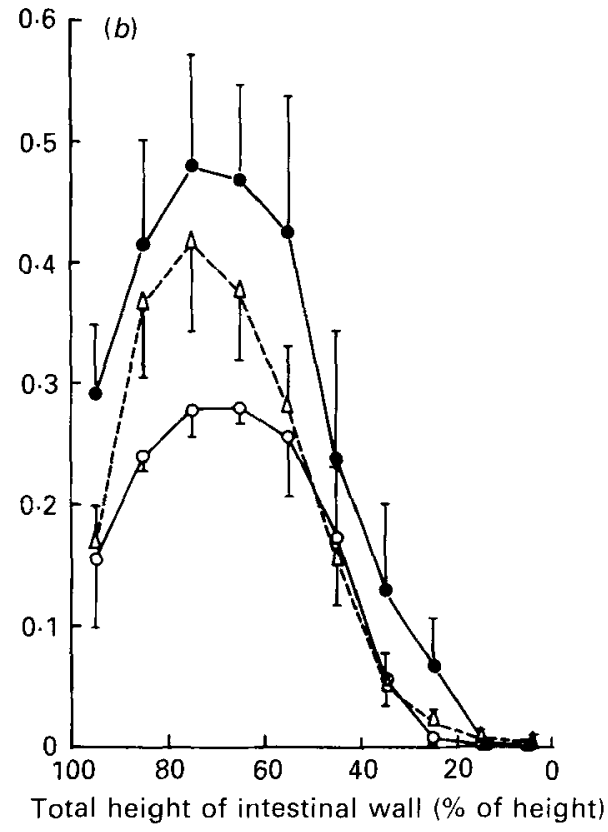

Villus

Fig. 4. Expt. 3. Lactase (EC 3.2.1.23) activity along the villus-crypt columns $6 \mathrm{~h}$ after the initiation of force feeding of the sucrose diet. The rats were killed at $(a) 10.00$ hours or $(b) 22.00$ hours. The abscissa depicts the total height of the intestinal wall, with $100 \%$ representing the apical part of the villus and $0 \%$ representing the bottom of the serosal side. ( $\square$ ), Villus region; ( $\square$ ) crypt region; the overlapping area is the crypt-villus transition (mix) zone. Points are means with their standard errors represented by vertical bars for four rats. (O), Low-starch diet (control); $(\triangle)$, sucrose diet for $6 \mathrm{~h} ;(\odot)$, sucrose diet for the entire experimental period.

increase of sucrase and lactase activity was similar to that seen in the rats killed at 10.00 hours (Figs $3(b)$ and $4(b)$ ). Sucrase activity of rats fed on diet S ad lib. for $7 \mathrm{~d}$ was markedly higher than both groups of rats fed on diet Lst (and force-fed with either diet Lst or diet $\mathrm{S}$ for $6 \mathrm{~h}$ ) along the entire height of the villus regardless of the time of killing (Fig. 3). Similarly, lactase activity of rats fed on diet $\mathrm{S}$ ad lib. for $7 \mathrm{~d}$ was higher than that of rats fed on diet Lst (and then force-fed for $6 \mathrm{~h}$ ) along the entire height of the villus at both 10.00 and 22.00 hours. However, within $6 \mathrm{~h}$ after the initial force-feeding with diet S, lactase activity reached the level seen in the rats fed on diet $S$ for $7 \mathrm{~d}$ at the upper part of the villus, but not in the lower part of the villus (Fig. 4).

\section{DISCUSSION}

The present study had confirmed and expanded previous studies in this laboratory (Yamada et al. 1981 a; Goda et al. 1984, 1985) and others (Cézard et al. 1983) which demonstrate that sucrase and lactase activities increase in the rat jejunum within a short time after the introduction of a high-carbohydrate diet. Although sucrase activity reaches a maximal level $24-48 \mathrm{~h}$ after the introduction of a sucrose-containing diet (Goda et al. 1985), feeding with diet $S$ led to a marked increase in sucrase and lactase activities within $12 \mathrm{~h}$; this increase was detectable as early as $6 \mathrm{~h}$ following the change to a highcarbohydrate diet.

This dictary effect was observed not only when disaccharidase activities were decreasing to minimum levels (i.e. between 22.00 and 10.00 hours), but also when they were increasing 
to peak levels (i.e. between 10.00 and 22.00 hours). The absolute increases in sucrase, maltase and lactase activities induced by feeding with diet $\mathrm{S}$ before 10.00 hours were identical to those induced by giving the same amount of diet $S$ before 22.00 hours. A twoway analysis of variance revealed that there was no significant interaction between the diet effect and the time effect, which suggested a constant (time-independent) effect of diet S. These results indicate that small intestinal epithelial cells retained the capability to respond to a dietary modification of carbohydrate at any time of the day, and that there was no diurnal variation of the 'adaptational' capability.

The lack of a diurnal variation of 'adaptational' capability of the enterocytes was further supported by analysis of the activities of lactase and sucrase along the height of the villus-crypt columns. The present findings showed that the distribution of cell cohorts that responded to the dietary manipulation with an increase in lactase and sucrase activities to the dietary manipulation was not affected by the time of introduction of diet $\mathrm{S}$. Furthermore, the present results are in agreement with a previous report (Goda et al. 1985), which revealed that the lower part of the villus is the major reactive site of sucrase activity, whereas the upper villus is the major reactive site of lactase activity.

The present study also revealed that a typical diurnal variation of small intestinal sucrase, maltase, and lactase activities (Saito, 1972; Stevenson et al. 1975) was seen in rats fed on diet Lst as well as in rats fed on diet Hst. It is interesting to note that the increase in disaccharidase activity between 10.00 and 22.00 hours is much greater on the high-starch diet than the low-starch diet. It is very likely that the extent of the diurnal variation of disaccharidase activities is affected by the amount of carbohydrate consumed. However, the pattern of diurnal variation (e.g. percentage changes) of disaccharidase activities was similar for the two dietary groups (Table 2). This result suggests that the pattern of diurnal variation of intestinal disaccharidase activities persists regardless of the amount of carbohydrate consumed. This is supported by the report of Saito et al. (1978) who demonstrated that diurnal variation of jejunal sucrase and maltase activities was seen even in rats fed on a carbohydrate-free diet. Thus, either the protein intake (Furuya et al. 1979) or the energy intake, rather than the carbohydrate intake, may be a major cue in maintaining a basal diurnal variation of disaccharidase activities.

Since our objective was to analyse quantitatively the capability of intestinal epithelial cells to respond to dietary carbohydrate at different times of the day, it was necessary to control food intake strictly. This was done by a force-feeding procedure for which we have previously established that lactase or sucrase activities, villus height and cell migration rates are not modified (Goda et al. 1984, 1985). However, since it is known that meal-feeding restricted to a short period of time (3-6 h/d) can cause a shift of peak activity of intestinal disaccharidases to the time of feeding (Saito et al. 1975, 1976), it was necessary to select the shortest time-period $(6 \mathrm{~h})$ of dietary manipulation that led to a profound effect on disaccharidase activities (Goda et al. 1985). In this regard, it is interesting to note that $6 \mathrm{~h}$ after the initial force-feeding of diet Lst, a clear diurnal variation of sucrase and maltase activities was still observed, whereas the diurnal variation of lactase activity was obscured (see Table 3). At $12 \mathrm{~h}$, the diurnal variation of sucrase and maltase activities remained, though it was less apparent, and the diurnal variation of lactase activity was completely abolished (see Table 4). These results suggest that $(a)$ the interruption of a diurnal variation of food intake caused by intermittent force-feeding of a constant amount of diet might lead to the disappearance of the diurnal variation of intestinal disaccharidase activities within a relatively short period of time (i.e. $6-12 \mathrm{~h}$ ), and $(b)$ the diurnal variation of lactase activity might be influenced by dietary manipulation in a shorter time than sucrase and maltase activities.

It should be noted that not only the activities of sucrase and maltase ( $\alpha$-glucosidases), but 
also the activity of lactase (a $\beta$-galactosidase), was affected by feeding with diet $\mathrm{S}$, and that lactase activity was modified according to diurnal variation. In contrast, the activity of another $\alpha$-glucosidase, trehalase, appeared to be regulated in a manner, distinct from the other disaccharidases. Trehalase activity exhibited a diurnal variation only when rats were fed on diet Hst; no diurnal variation was detected in rats fed on diet Lst. Furthermore, trehalase activity is dependent on carbohydrate intake only when it is measured at a time when diet consumption is high. This observation supports the results of Shinohara et al. (1986), who showed no effect of carbohydrate intake on trehalase activity in rats killed in the morning.

The mechanism by which the diurnal variation of small intestinal disaccharidase activities is expressed is not clear. Kaufman et al. (1980) have proposed that the diurnal variation of sucrase activity is based on a variation in the rate of degradation, as opposed to the rate of synthesis, of sucrase-isomaltase. In their report Kaufman et al. (1980) showed that the rate of degradation of sucrase was much slower when a carbohydrate-containing diet was provided than when the diet was removed. Since many investigators have demonstrated that pancreatic secretions play a role in the degradation of sucrase-isomaltase and lactase (Alpers \& Tedesco, 1975; Goda \& Koldovskỳ, 1985; Riby \& Kretchmer, 1985; Goda et al. 1988), it is conceivable that a cyclic pattern of pancreatic protease(s) could be responsible for diurnal variation of disaccharidase activities. However, no diurnal variation of lumen trypsin activity was observed in rats fed on a standard laboratory diet (Goda \& Koldovsky, 1985) or in those fed on diets Lst or Hst (present report). This suggests that the secretion or activation of trypsinogen, or both, is not involved in the expression of a diurnal variation of disaccharidase activities. This agrees with the lack of cyclic change of pancreatic content of trypsinogen (George et al. 1985) and absence of cyclic change of rate of synthesis of trypsinogen in the pancreas (Girard-Globa et al. 1980). The involvement of other proteases (e.g. chymotrypsin (EC 3.4.21.1), elastase (EC 3.4.21.36), however, cannot be excluded at present.

In contrast to the diurnal variation of sucrase activity, the dietary-induced increase in sucrase activity has been shown to occur with a concomitant increase in the rate of synthesis of sucrase-isomaltase in rats previously fed on a carbohydrate-free diet (Cézard et al. 1983). It has also been shown that in rats fed on a high-carbohydrate diet for a few days, the rate of incorporation of a precursor amino acid into sucrase-isomaltase (Riby \& Kretchmer, 1984; Tsuboi et al. 1985), lactase (Tsuboi et al. 1985) and glucoamylase (EC 3.2.1.3) (Tsuboi et al. 1985) is increased, compared with rats fed on a low-starch diet. Further studies are needed to explore the molecular mechanisms involved in these two apparently independent variations in microvillar disaccharidase activities in the small intestine.

This work was supported by National Institutes of Health Grant DK27624. Portions of these studies were conducted in partial fulfilment for a Master of Science degree at the University of Arizona (B.K.S.) and were presented at the 1986 FASEB Meeting.

\section{REFERENCES}

Alpers, D. H. \& Tedesco, F. J. (1975). The possible role of pancreatic proteases in the turnover of intestinal brush border proteins. Biochimica et Biophysica Acta 401, 28-40.

American Institute of Nutrition (1977). Report of the American Institute of Nutrition Ad Hoc Committee on standards for nutritional studies. Journal of Nutrition 107, 1340-1348.

Cézard, J. P., Broyart, J. P., Cuisinier-Gleizes, P. \& Mathieu, H. (1983). Sucrase-isomaltase regulation by dietary sucrose in the rat. Gastroenterology 84, $18-25$.

Dahlqvist, A. (1964). Method for assay of intestinal disaccharidases. Analytical Biochemistry 7, $18-25$.

Erlanger, B. F., Kokowsky, N. \& Cohen, W. (1961). The preparation and properties of two new chromogenic substrates of trypsin. Archives of Biochemistry and Biophysics 95, 271-278. 
Furuya, S., Sitren, H. S., Zeigen, S., Offord, C. E. \& Stevenson, N. R. (1979). Alterations in the circadian rhythmicity of rat small intestinal functions. Journal of Nutrition 109, 1962-1973.

George, D. E., Lebenthal, E., Landis, M. \& Lee, P. C. (1985). Circadian rhythm of the pancreatic enzymes in rat: its relation to small intestinal disaccharidases. Nutrition Research 5, 651662.

Girard-Globa, A., Bourdel, G. \& Lardeux, B. (1980). Regulation of protein synthesis and enzyme accumulation in the rat pancreas by amount and timing of dietary protein. Journal of Nutrition 110, 1380-1390.

Goda, T., Bustamante, S. \& Koldovskỳ, O. (1985). Dietary regulation of intestinal lactase and sucrase in adult rats: quantitative comparison of effect of lactose and sucrose. Journal of Pediatric Gastroenterology and Nutrition 4, 998-1008.

Goda, T., Bustamante, S., Thornburg, W. \& Koldovskỳ, O. (1984). Dietary-induced increase of lactase activity and in immunoreactive lactase in adult rat jejunum. Biochemical Journal 221, 261-263.

Goda, T. \& Koldovskỳ, O. (1985). Evidence of degradation process of sucrase-isomaltase in jejunum of adult rats. Biochemical Journal 229, 751-758.

Goda, T. \& Koldovsky, O. (1988). Dietary regulation of small intestinal disaccharidases. In World Review of Nutrition and Dietetics, vol. 57, pp. 275-329 [G. H. Bourne, editor]. Basel, Karger Medical Publishing Co.

Goda, T., Quaroni, A. \& Koldovskỳ, O. (1988). Characterization of degradation process of sucrase-isomaltase in rat jejunum with monoclonal antibody-based enzyme-linked immunosorbent assay. Biochemical Journal 250, $41-46$.

Goda, T., Yamada, J., Bustamante, S. \& Koldovskỳ, O. (1983). Dietary-induced rapid decrease of microvillar carbohydrase activity in at jcjunoileum. American Journal of Physiology 245, G418-G423.

Kaufman, M. A., Korsmo, H. A. \& Olsen, W. A. (1980). Circadian rhythm of intestinal sucrase activity in rats. Mechanism of enzyme change. Journal of Clinical Investigation 65, $1174-1181$.

Koldovsky, O., Asp, N. G. \& Dahlqvist, A. (1969). A method for the separate assay of 'neutral' and 'acid ' $\beta$ galactosidase in homogenates of rat small intestinal mucosa. Analytical Biochemistry 27, 409-418.

Lowry, O. H., Rosebrough, N. J., Farr, A. L. \& Randall, R. J. (1951). Protein measurement with the Folin phenol reagent. Journal of Biological Chemistry 193, $265-275$.

Riby, J. E. \& Kretchmer, N. (1984). Effect of dietary sucrose on synthesis and degradation of intestinal sucrase. American Journal of Physiology 246, G757-G763.

Riby, J. E. \& Kretchmer, N. (1985). Participation of pancreatic enzymes in the degradation of intestinal sucraseisomaltase. Journal of Pediatric Gastroenterology and Nutrition 4, 971-979.

Saito, M. (1972). Daily rhythmic changes in brush border enzymes of the small intestine and kidney in rat. Biochimica et Biophysica Acta 286, 212-215.

Saito, M., Murakami, E., Nishida, T., Fujisawa, Y. \& Suda, M. (1975). Circadian rhythms in digestive enzymes in the small intestine of rats. 1. Patterns of the rhythms in various regions of the small intestine, Journal of Biochemistry 78, 475-480.

Saito, M., Murakami, E. \& Suda, M. (1976). Circadian rhythms in disaccharidases of rat small intestine and its relation to food intake. Biochimica et Biophysica Acta 421, 177-179.

Saito, M., Sato, Y. \& Suda, M. (1978). Circadian rhythm and dietary response of disaccharidase activities in isolated rat jejunum. Gastroenterology 75, 828-831.

Semenza, G. (1986). Anchoring and biosynthesis of stalked brush border membrane proteins: glycosidases and peptidases of enterocytes and of renal tubuli. Annual Review of Cell Biology 2, 255-313.

Shinohara, H., Tsuji, Y., Yamada, K. \& Hosoya, N. (1986). Effects of carbohydrate intake on disaccharidase activity and disaccharide-evoked transmural potential difference in rat small intestine. Journal of the Japanese Society of Nutrition and Food Science 39, 35-41.

Stevenson, N. R., Ferrigni, F., Parnicky, K., Day, S. \& Fierstein, J. S. (1975). Effect of changes in feeding schedule on the diurnal rhythms and daily activity levels of intestinal brush border enzymes and transport systems. Biochimica et Biophysica Acta 406, 131 145.

Tsuboi, K. K., Kwong, L. K., Yamada, K., Sunshinc, P.\& Koldovskỳ, O. (1985). Nature of elevated rat intestinal carbohydrase activities after high-carbohydrate diet feeding. American Journal of Physiology 249, G510-G518.

Yamada, K., Bustamante, S. \& Koldovsky, O. (1981 $a$ ). Dietary-induced rapid increase of rat jejunal sucrase and lactase activity on all regions of the villus. FEBS Letters $129,89-92$.

Yamada, K., Bustamante, S. \& Koldovskỳ, O. (1981 b). Time- and dose-dependency of intestinal lactase activity in adult rat on starch intake. Biochimica et Biophysica Acta 676, 108-112. 